\title{
Characterization of Antisera Specific to NK1, NK2, and NK3 Neurokinin Receptors and their Utilization to Localize Receptors in the Rat Gastrointestinal Tract
}

\author{
Eileen F. Grady, ${ }^{1}$ Peter Baluk, ${ }^{2,5}$ Stephan Böhm, ${ }^{1}$ Patrick D. Gamp, ${ }^{1}$ Helen Wong, ${ }^{6}$ Donald G. Payan, ${ }^{3}$ \\ John Ansel,7 Andrea L. Portbury, ${ }^{8}$ John B. Furness, ${ }^{8}$ Donald M. McDonald, ${ }^{2,5}$ and Nigel W. Bunnett ${ }^{1,4}$ \\ Departments of ${ }^{1}$ Surgery, ${ }^{2}$ Anatomy, ${ }^{3}$ Medicine, and ${ }^{4}$ Physiology, and the ${ }^{5}$ Cardiovascular Research Institute, University \\ of California, San Francisco, California 94143; 'CURE VA/University of California Los Angeles Gastroenteric Biology \\ Center, Los Angeles, California 90095; '7Department of Dermatology, Emory University, Atlanta, Georgia 30322; and \\ ${ }^{8}$ Department of Anatomy and Cell Biology, University of Melbourne, Parkville Victoria 3052, Australia
}

\begin{abstract}
Understanding the physiological role of tachykinins requires precise cellular and subcellular localization of their receptors. We raised antisera by immunizing rabbits with peptides corresponding to portions of the intracellular tails of the rat neurokinin 1, 2, and 3 receptors (NK1-R, NK2-R, NK3-R). Receptors were localized by immunofluorescence and confocal microscopy. NK1-R, NK2-R, and NK3-R were detected at the plasma membrane of transfected cells with minimal intracellular stores. Staining was abolished by preabsorption of the antisera with the peptides used for immunization. Nontransfected cells were unstained. Each antiserum only stained cells transfected with the appropriate receptor and did not stain cells transfected with the other receptors. Therefore, the antisera are specific and do not cross-react with other neurokinin receptors. We examined the distribution of the neurokinin receptors in the gastrointes-
\end{abstract}

tinal tract of the rat. NK1-R was detected in myenteric and submucosal neurons and in interstitial cells of Cajal. NK2-R was localized to circular and longitudinal muscle cells and to nerve endings in the plexuses. NK3-R was detected in numerous myenteric and submucosal neurons. Some neurons expressed both NK1-R and NK3-R. Receptors were detected at the plasma membrane and in endosomes. Cells expressing the receptors were closely associated with tachykinin-containing nerve fibers. Thus, NK1-R and NK3-R mediate neurotransmission by tachykinins within enteric nerve plexuses, and NK1-R and NK2-R mediate the effects of tachykinins on interstitial and smooth muscle cells, respectively.

Key words: tachykinins; neurokinin receptors; receptor antisera; enteric neurons; interstitial cells of Cajal; smooth muscle
The tachykinin family of neuropeptides includes substance P (SP), neurokinin A (NKA), and neurokinin B (NKB). They are neurotransmitters in the peripheral and central nervous systems, stimulate smooth muscle contraction and exocrine secretion, and mediate inflammation (Otsuka and Yoshioka, 1993). The tachykinins interact with three G-protein-coupled neurokinin receptors (NK1-R, NK2-R, and NK3-R) with different affinities (NK1-R: SP > NKA > NKB; NK2-R: NKA > NKB > SP; NK3-R: NKB > NKA > SP) (Helke et al., 1990; Ohkubo and Nakanishi, 1991). The ability of a tachykinin to interact with a receptor depends on the proximity of sites of peptide release to receptor-bearing cells, so that the required peptide concentration for receptor activation is achieved, and on whether a receptor is available and appropriately coupled. Therefore, an understanding of the physiological functions of the tachykinins requires precise localization of the peptides and their receptors. The distribution of the tachykinins has been studied thoroughly by molecular, biochemical, and immunohistochemical techniques (Otsuka and Yoshioka, 1993). SP and NKA are usually coexpressed and are found in high concen-

Received March 18, 1996; revised July 12, 1996; accepted Aug. 16, 1996.

This work was supported by National Institutes of Health Grants DK39957, DK43207, NS21710, HD33024, and HL 24136. We thank Dr. J. E. Krause for supplying cells transfected with NK2-R and for NK3-R cDNA. We thank Dr. J. H. Walsh for help in choosing the receptor fragments that were used for immunization. Correspondence should be addressed to Nigel W. Bunnett, University of California, San Francisco, 521 Parnassus Avenue, San Francisco, CA 94143-0660.

Copyright (C) 1996 Society for Neuroscience $0270-6474 / 96 / 166975-12 \$ 05.00 / 0$ trations in the peripheral and central nervous systems, whereas NKB is confined mostly to the CNS.

Far less is known about the distribution of the neurokinin receptors, because specific antisera have not been available. Neurokinin receptors have been detected by autoradiography (Burcher et al., 1984, 1986, 1993; Mantyh et al., 1988, 1989; Gates et al., 1989). Binding sites for all three peptides are present in the brain and spinal cord, whereas sites for only SP and NKA are found in the gastrointestinal tract. Autoradiography localizes functional binding sites but has inadequate resolution for precise cellular and subcellular localization. Neurokinin receptors have been localized in cells with high resolution using fluorescent ligands (Garland et al., 1994; Bunnett et al., 1995; Grady et al., 1995, 1996). However, fluorescent and radiolabeled peptides interact with more than one neurokinin receptor or may detect binding sites that are not receptors. Localization of receptors has also been inferred from pharmacological studies using selective agonists and antagonists (Regoli et al., 1994). This approach again relies on binding properties, resulting in a lack of absolute specificity.

Neurokinin receptors have been cloned from several species, including the rat (Yokota et al., 1989; Sasai and Nakanishi, 1989; Hershey and Krause, 1990; Shigemoto et al., 1990), permitting molecular analysis of receptor distribution. NK1-R mRNA is expressed in relatively high levels in the CNS and gastrointestinal tract, NK2-R mRNA is mostly confined to peripheral organs, and NK3-R mRNA is found mostly in the CNS (Tsuchida et al., 1990). 
An important step in resolving the difficulty of accurate and precise localization is the development of receptor specific antisera that are suitable for immunocytochemistry. Thus, our aims were as follows: (1) to generate antisera to the rat NK1-R, NK2-R, and NK3-R; (2) to characterize the antisera by immunofluorescence and Western blotting in transfected cells; (3) to localize the receptors at the cellular and subcellular level in the rat gastrointestinal tract by immunofluorescence and confocal microscopy; and (4) to verify that they are localized near tachykinincontaining nerves.

\section{MATERIALS AND METHODS}

Materials. Keyhole limpet hemocyanin was from Calbiochem (La Jolla, CA) or Pierce (Rockford, IL), carbodiimide was from ICN (Irvine, CA), $m$-maleimidobenzoyl- $N$-hydroxysuccinimide ester was from Pierce, Freund's adjuvant was from Difco Laboratories (Detroit, MI), and TriImmunol vaccine was from Lederle Laboratories (Pearl River, NY). An ECL detection kit was from Amersham (Arlington Heights, IL). Fura-2 $\mathrm{AM}$ and Cell Tracker CM-DiI were from Molecular Probes (Eugene, OR). Affinity-purified goat anti-mouse and goat anti-rabbit IgG, coupled to FITC or Texas Red, were from Cappel Research Products (Durham, NC) or Jackson ImmunoResearch (West Grove, PA). A monoclonal antibody to tachykinins was from Chemicon (Temecula, CA). SP, NKA, and NKB were from Peninsula Laboratories (Belmont, CA). Other reagents were from Sigma (St. Louis, MO).

Cell lines. Sarcoma virus-transformed rat kidney epithelial cells (KNRK) and Chinese hamster ovary cells (CHO) were from American Tissue Type Culture Collection (Rockville, MD). KNRK cells stably expressing the rat NK1-R were generated as described previously (Okamoto et al., 1994; Vigna et al., 1994). CHO cells stably expressing the rat NK2-R were a gift from Dr. J. E. Krause (Washington University, St. Louis, MO). KNRK were stably transfected with cDNA encoding the rat NK3-R (gift from Dr. J. E. Krause) as described previously (Okamoto et al., 1994; Vigna et al., 1994). Cells were maintained in minimal essential medium- $\alpha$ supplemented with $10 \%$ fetal bovine serum, $100 \mathrm{U} / \mathrm{ml}$ penicillin, $100 \mu \mathrm{g} / \mathrm{ml}$ streptomycin, and $400 \mu \mathrm{g} / \mathrm{ml} \mathrm{G}-418$ in $5 \% \mathrm{O}_{2} / 95 \% \mathrm{CO}_{2}$ at $37^{\circ} \mathrm{C}$.

Cells were screened for functional expression of neurokinin receptors by measurement of changes in $\left[\mathrm{Ca}^{2+}\right]_{\mathrm{i}}$ in response to tachykinins using Fura-2 AM (Okamoto et al., 1994; Vigna et al., 1994). Fluorescence was measured in a spectrofluorometer at wavelengths of 340 and $380 \mathrm{~nm}$ for excitation and $510 \mathrm{~nm}$ for emission. The ratio of the fluorescence at the two excitation wavelengths, which is proportional to the $\left[\mathrm{Ca}^{2+}\right]_{i}$, was calculated. SP, NKA, and NKB (10 nM) induced a prompt increase in $\left[\mathrm{Ca}^{2+}\right]_{\mathrm{i}}$ in cell lines expressing NK1-R, NK2-R, and NK3-R, respectively (data not shown). There was no detectable $\mathrm{Ca}^{2+}$ response to these peptides in nontransfected cells. Therefore, the transfected cell lines express functional neurokinin receptors, but these receptors are undetectable in nontransfected cells. Cells respond to agonists at concentrations similar to the affinity of each receptor for its high-affinity ligand (Yokota et al., 1989; Hershey and Krause, 1990; Krause et al., 1990; Shigemoto et al., 1990; Ingi et al., 1991, Ohkubo and Nakanishi, 1991).

Generation of polyclonal antisera. Peptide fragments corresponding to the intracellular C-terminal tails of the rat NK1-R $\left({ }^{393}\right.$ KTMTESSSFYSNML ${ }^{407} \mathrm{~A}$ COOH, NK1-R $\left.393-407\right)$, rat NK2-R ( ${ }^{376} \mathrm{YQDGEPAGPICKAQ}^{390} \mathrm{~A} \mathrm{COOH},{ }^{376} \mathrm{P} \rightarrow \mathrm{Y}$ substitution, NK2$\left.\mathrm{R}_{376-390}\right)$, and rat NK3-R ( $\left({ }^{438}\right.$ SSFISSPYTSVDEY ${ }^{452} \mathrm{~S}$ COOH, NK3$\mathrm{R}_{438-452}$ and $\left.{ }^{410} \mathrm{SSRKKR}{ }^{417} \mathrm{~A} \mathrm{COOH}, \mathrm{NK} 3-\mathrm{R}_{410-417}\right)$ were synthesized by solid phase methods and purified by reversed-phase HPLC (Ohkubo and Nakanishi, 1991). For conjugation of NK1-R fragment, $7 \mathrm{mg}$ of NK1-R ${ }_{393-407}, 5 \mathrm{mg}$ of keyhole limpet hemocyanin, and $30 \mathrm{mg}$ of carbodiimide were dissolved in $3.0 \mathrm{ml}$ of $50 \mathrm{~mm}$ PBS, pH 7.4, gently agitated for $3 \mathrm{hr}$ at room temperature and overnight at $4^{\circ} \mathrm{C}$, and dialyzed. The efficiency of conjugation, estimated by including $10^{5} \mathrm{cpm}$ of ${ }^{125}$ I-labeled NK1-R $393-407$ in the reaction, was $\sim 30 \%$. For conjugation of NK2-R fragment, $5 \mathrm{mg}$ of NK2-R $\mathrm{R}_{376-390}$ and $5 \mathrm{mg}$ of keyhole limpet hemocyanin were dissolved in $3 \mathrm{ml}$ of $0.13 \mathrm{M} \mathrm{NaCl}$ in $0.16 \mathrm{M}$ boric acid, pH-adjusted to 9.0 , on ice. Bisdiazotized benzidine $(25 \mathrm{~mm}$, $150 \mu \mathrm{l})$ was added dropwise with continuous stirring, the reaction was continued for $3 \mathrm{hr}$, and the mixture was dialyzed. The efficiency of conjugation was $\sim 70 \%$. For conjugation of NK3-R fragment, $10 \mathrm{mg}$ of NK3-R $438-452$ and $5 \mathrm{mg}$ of keyhole limpet hemocyanin were dissolved in $6 \mathrm{ml}$ of $0.01 \mathrm{M}$ ammonium acetate, $\mathrm{pH} \mathrm{5.2,} \mathrm{and} 10 \mu \mathrm{l}$ of $25 \%$ glutaraldehyde solution was added. The mixture was agitated in the dark for $3 \mathrm{hr}$ at room temperature and dialyzed. The efficiency of conjugation was $\sim 70 \%$. In addition, $1 \mathrm{mg}$ of the NK3- $\mathrm{R}_{410-417}$ fragment was conjugated to $10 \mathrm{mg}$ of keyhole limpet hemocyanin with $m$-maleimidobenzoyl- $N$-hydroxysuccinimide ester.

Three female New Zealand rabbits (10 weeks) were used for immunization with each peptide conjugate. The conjugates were mixed 1:1 with Freund's complete adjuvant, and rabbits were immunized with $2.0 \mathrm{ml}$ of the emulsion, containing $\sim 80-500 \mu \mathrm{g}$ of conjugates in $15-20$ sites at $6-8$ week intervals. At the first immunization, rabbits were injected intramuscularly with $0.5 \mathrm{ml}$ of Tri-Immunol vaccine. Animals were boosted every $6-8$ weeks with $40-200 \mu \mathrm{g}$ of conjugated peptide in Freund's incomplete adjuvant.

Antiserum screening by ELISA. The peptides used for immunization (500 ng peptide/well) were attached to 96-well plates by incubation with $50 \mu \mathrm{l}$ of $10 \mu \mathrm{g} / \mathrm{ml}$ peptide in PBS overnight at $4^{\circ} \mathrm{C}$. Plates were blocked with $1 \%$ bovine serum albumin in PBS for $1 \mathrm{hr}$ at room temperature and washed with PBS containing $0.01 \%$ Tween-20, and $100 \mu \mathrm{l}$ of diluted antisera $(1: 10$ to $1: 100,000)$ was added per well. Plates were incubated for $1 \mathrm{hr}$ at $37^{\circ} \mathrm{C}$, washed, and incubated with $100 \mu \mathrm{l}$ of 1:1000 horseradish peroxidase-conjugated goat anti-rabbit IgG for $1 \mathrm{hr}$ at $37^{\circ} \mathrm{C}$. Plates were washed and incubated with $100 \mu \mathrm{l}$ of $o$-phenylenediamine dihydrochloride in $0.1 \mathrm{M}$ citrate buffer, $\mathrm{pH} 5.0$, containing $0.015 \% \mathrm{H}_{2} \mathrm{O}_{2}$ for $15 \mathrm{~min}$ at $37^{\circ} \mathrm{C}$, to develop the reaction product. Reactions were stopped by addition of $50 \mu \mathrm{l}$ of $10 \% \mathrm{H}_{2} \mathrm{SO}_{4}$, and absorbance was measured at $492 \mathrm{~nm}$.

Western blotting. Cells were solubilized in Laemmli buffer by boiling for $5 \mathrm{~min}$. Aliquots (10 $\mu \mathrm{g}$ total protein/lane) were separated on a $4-15 \%$ polyacrylamide gel under denaturing and reducing conditions (Laemmli, 1970) and transferred to nitrocellulose. Filters were incubated with the antisera (1:5000) overnight at $4^{\circ} \mathrm{C}$, washed, and then incubated with goat anti-rabbit $\operatorname{IgG}$ conjugated to peroxidase $(1: 8000)$ for $1 \mathrm{hr}$ at room temperature. Bands were detected using an Amersham ECL detection kit according to the manufacturer's protocol. Controls included use of nontransfected cells and preabsorption of the diluted primary antisera with receptor fragments $(1 \mu \mathrm{g} / \mathrm{ml})$ for $1 \mathrm{hr}$ at room temperature before incubation with the filter.

Receptor localization in transfected cell lines. Cells were plated on poly-D-lysine-coated glass coverslips for $2 \mathrm{~d}$ before use. Cells were fixed in

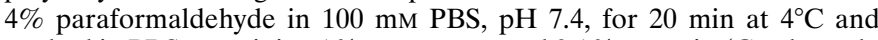
washed in PBS containing $1 \%$ goat serum and $0.1 \%$ saponin (Grady et al., 1995). Cells were incubated with primary antibodies (1:1000 to $1: 5000)$ overnight at $4^{\circ} \mathrm{C}$ and with FITC- or Texas Red-conjugated goat antirabbit $\operatorname{IgG}(1: 200)$ for $2 \mathrm{hr}$ at room temperature.

Receptor localization in tissue sections and whole mounts. Male Sprague Dawley rats $(200 \mathrm{gm})$ were anesthetized with sodium pentobarbital (60 $\mathrm{mg} / \mathrm{kg}$, i.p.) and transcardially perfused with $50 \mathrm{ml}$ of PBS containing 100 $\mathrm{U}$ of heparin followed by $500 \mathrm{ml}$ of $4 \%$ paraformaldehyde in $100 \mathrm{~mm}$ PBS, $\mathrm{pH}$ 7.4. Tissues were removed, placed in fixative overnight at $4^{\circ} \mathrm{C}$, and washed in PBS. For preparing cryostat sections, tissues were incubated in $25 \%$ sucrose in PBS for $24 \mathrm{hr}$ at $4^{\circ} \mathrm{C}$, embedded in OCT compound (Miles, Elkhart, IN), and sectioned at $10 \mu \mathrm{m}$. For preparing whole mounts, the longitudinal muscle with attached myenteric plexus, circular muscle, and submucosa was dissected from the terminal ileum. Sections and whole mounts were washed in PBS containing 1-10\% goat serum and $0.3 \%$ Triton X-100 and incubated with primary antisera (1:1000 to 1:4000) for $24-48 \mathrm{hr}$ at $4^{\circ} \mathrm{C}$ and with FITC- or Texas Red-conjugated goat anti-rabbit $\operatorname{IgG}(1: 200)$ for $2 \mathrm{hr}$ at room temperature. For simultaneous localization of the neurokinin receptors and tachykinins, sections and whole mounts were incubated with the polyclonal receptor antisera and a monoclonal tachykinin antiserum (1:1000), followed by speciesspecific secondary antibodies conjugated with contrasting fluorophores. For detection of the cell surface, stained sections were incubated further with $0.5 \mu \mathrm{g} / \mathrm{ml}$ Cell Tracker CM-DiI for $30 \mathrm{~min}$ at room temperature and post-fixed with $4 \%$ paraformaldehyde.

Microscopy. Cells and tissues were examined using an MRC 1000 Laser Scanning Confocal Microscope (Bio-Rad, Hercules, CA) equipped with a krypton/argon laser and attached to a Zeiss Axiovert microscope. A Zeiss Plan-Apochromat $\times 100$ oil-immersion objective with a numerical aperture of $1.4(\infty 0.7)$ was used. Images were collected using an aperture of $2-4 \mathrm{~mm}$ and a zoom of 1-4. Usually, 12-20 optical sections were taken at $0.54 \mu \mathrm{m}$ intervals. The resolution of the confocal microscope in the $x / y$-axis was $170-200 \mathrm{~nm}$ and in the $z$-axis $230-400 \mathrm{~nm}$. Images of $768 \times$ 520 pixels were obtained. Images were processed using Adobe Photoshop 3.0 (Adobe Systems, Mountain View, CA) and printed using a Fujix Pictrography 3000 Printer. All images are of a single optical section. 


\section{RESULTS}

\section{Generation of antibodies}

We obtained serum from all rabbits after the second and subsequent booster injections and screened for the presence of receptor antibodies by ELISA and by immunofluorescence with transfected cell lines. Antibodies that were detectable by ELISA and by immunofluorescence were obtained in all rabbits after the second boosts with ELISA titers from 1:10,000 to 1:100,000 (Table 1). For the immunofluorescence studies, we used the following antisera: NK1-R, \#94168; NK2-R, \#94179; NK3-R, \#94192 and \#AP951, based on the intensity of staining of transfected cells.

\section{Characterization of antibodies in transfected cell lines}

We used cell lines that were stably transfected with cDNA encoding the rat NK1-R, NK2-R, or NK3-R to characterize fully the receptor antibodies by immunofluorescence and Western blotting.

We localized the receptors in the transfected cells by immunofluorescence and confocal microscopy. The NK1-R, NK2-R, and NK3-R antisera stained the plasma membrane of cells expressing NK1-R, NK2-R, and NK3-R, respectively (Fig. 1). There was minimal receptor immunoreactivity in the cytoplasm or in organelles. Specificity was examined by preincubation of the diluted antisera with $1 \mu \mathrm{m}$ of the receptor fragments that were used for immunization. When antisera were absorbed with the receptor fragments and then incubated with transfected cells, there was no detectable staining (Fig. 1, bottom panels). Similarly, the antisera did not stain nontransfected cells (not shown). Therefore, the antisera specifically recognize the appropriate receptors in transfected cell lines.

The antisera were raised to peptides corresponding to C-terminal sequences of the rat NK1-R, NK2-R, and NK3-R that are distinctly different. Comparable sequences were not present in other proteins as determined by searches of available protein sequences in GenBank. We determined whether the antisera cross-reacted with other neurokinin receptors. Cells expressing NK1-R were only stained with NK1-R antiserum and not with NK2-R or NK3-R antisera (Fig. 1). Similarly, cells expressing NK2-R were stained only by NK2-R antiserum (Fig. 1), and cells expressing NK3-R were stained only by NK3-R antiserum (Fig. 1). Therefore, the antisera do not cross-react with the other known

Table 1. Detection of NK1-R, NK2-R, and NK3-R by ELISA and immunofluorescence with transfected cells after the second immunization

\begin{tabular}{lcll} 
Antigen & Number & $\begin{array}{l}\text { Titer by } \\
\text { ELISA }\end{array}$ & $\begin{array}{l}\text { Receptor } \\
\text { localization } \\
\text { in cell lines }\end{array}$ \\
\hline NK1-R & 94167 & $1: 20,000$ & ++ \\
& $94168^{*}$ & $1: 20,000$ & ++ \\
NK2-R & 94169 & $1: 10,000$ & +++ \\
& $94176-390$ & $1: 100,000$ & ++ \\
& 94178 & $1: 50,000$ & + \\
NK3-R & $94179^{*}$ & $1: 100,000$ & +++ \\
& 94191 & $1: 50,000$ & + \\
NK3- $_{432}$ & $94192^{*}$ & $1: 100,000$ & +++ \\
& 94193 & $1: 100,000$ & ++ \\
\hline
\end{tabular}

The staining intensity is indicated by +++ (strong surface staining detected at high antisera dilutions), ++ (moderate staining), or + (weak staining only detected at low antisera dilutions). *, Antisera selected for further study. neurokinin receptors and can be used to specifically identify the neurokinin receptors.

We verified the specificity of our antisera by Western blot analysis. Each antiserum detected proteins in transfected cells expressing the appropriate receptor. The protein bands were broad, with molecular weights ranging from 80 to $100 \mathrm{kDa}$ (Fig. 2, lane 1). The largest molecular weight protein was detected in cells expressing the NK2-R. When antisera were preabsorbed with the receptor fragments that were used for immunization, there was no detectable staining of the blots (Fig. 2, lane 2). Similarly, there was no detectable staining of blots of nontransfected cells (Fig. 2, lane $3)$. Therefore, the antisera specifically recognize appropriate proteins in transfected cells.

\section{Localization of neurokinin receptors in the rat gastrointestinal tract}

Having characterized the antisera, we localized the neurokinin receptors in the rat gastrointestinal tract. There is evidence for expression of all three neurokinin receptors in this tissue (Otsuka and Yoshioka, 1993; Regoli et al., 1994).

\section{NK1-R}

NK1-R was detected in myenteric and submucosal neurons of the duodenum, jejunum, ileum, and colon and in myenteric neurons of the stomach, using antiserum \#94168 and confocal microscopy (Fig. 3A-C,E). The antiserum reacted with many, but not all, neurons in myenteric or submucosal ganglia. In whole mounts of the ileum, most of the NK1-R-expressing neurons in the myenteric plexus had the appearance of bipolar neurons, with two long processes extending parallel to the circular muscle fibers, or of cells with numerous short process (Fig. $3 C$ ). The NK1-R was also detected on numerous non-neuronal cells of the inner portion of the circular muscle of the small intestine (Fig. $3 B, D, E$ ). These cells were elongated, appeared to form a continuous layer, and had a higher density of NK1-R than neurons, as shown by the relative intensity of neuronal and non-neuronal immunoreactivity in Figure $3 B$. They resemble interstitial cells of Cajal, judging from their size, shape, and location. In both neuronal and nonneuronal cells, NK1-R was localized to the plasma membrane and to endosomes located beneath the plasma membrane or in a perinuclear location, as seen in optical sections taken through the center of these cells (Fig. $3 C-E$ ). In most neuronal processes, there were numerous endosomes and surface staining was less apparent than in the cell body. There was no detectable staining when the antiserum was preabsorbed with the peptide that was used for immunization (not shown). Examination of serial sections cut at $8 \mu \mathrm{m}$ intervals indicated that some neurons that expressed the NK1-R also expressed the NK3-R (Fig. 3E, F).

\section{NK2-R}

NK2-R was detected in the muscularis externa of the stomach, small intestine, and colon using antiserum \#94179 (Fig. 4). In the duodenum, jejunum, and ileum, both the circular and the longitudinal muscle layers were clearly stained with a similar intensity in each region (Fig. 4A). In the fundus and antrum of the stomach, the circular muscle was strongly stained, but there were very low levels of detectable immunoreactivity in the longitudinal muscle (Fig. 4C). The most intense staining was in the circular muscle layer of the antrum, where the plasma membrane of all muscle cells was clearly stained. In the proximal colon, the circular muscle showed a gradient of NK2-R immunoreactivity, with the high intensity of staining localized near the submucosa and a lower intensity occurring near the myenteric plexus (Fig. 4D). 

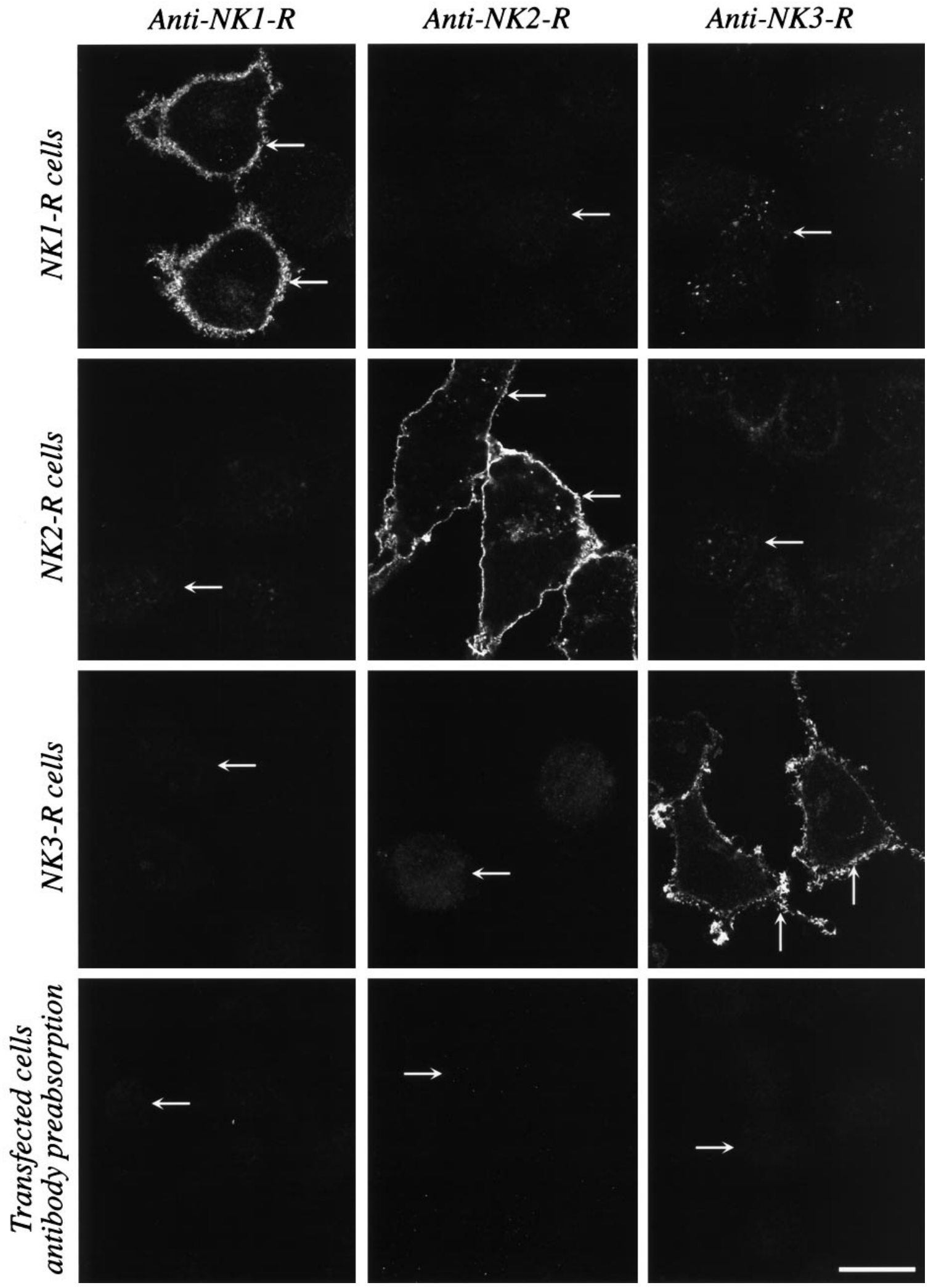

Figure 1. Confocal photomicrographs showing localization of NK1-R, NK2-R, and NK3-R in cell lines. The top horizontal panels show KNRK-NK1-R cells, the second horizontal panels show CHO-NK2-R cells, and the third horizontal panels show KNRK-NK3-R cells. The bottom horizontal panels show transfected cell lines expressing NK1-R (left), NK2-R (middle), and NK3-R (right). Cells were incubated with NK1-R antiserum (\#94168, left vertical panels), NK2-R antiserum (\#94179, middle vertical panels), and NK3-R antiserum (\#94192, right vertical panels), followed by Texas Red or FITCconjugated secondary antibodies. The bottom horizontal panels show transfected cells that were incubated with antisera preabsorbed with the peptides used for immunization. The arrows indicate that the antisera stain the plasma membrane of cells expressing the appropriate receptor and do not cross-react with cells expressing the other receptors. The arrows in the bottom horizontal panels indicate that staining was abolished by preabsorption with the receptor fragment used for immunization. Scale bar, $20 \mu \mathrm{m}$. 


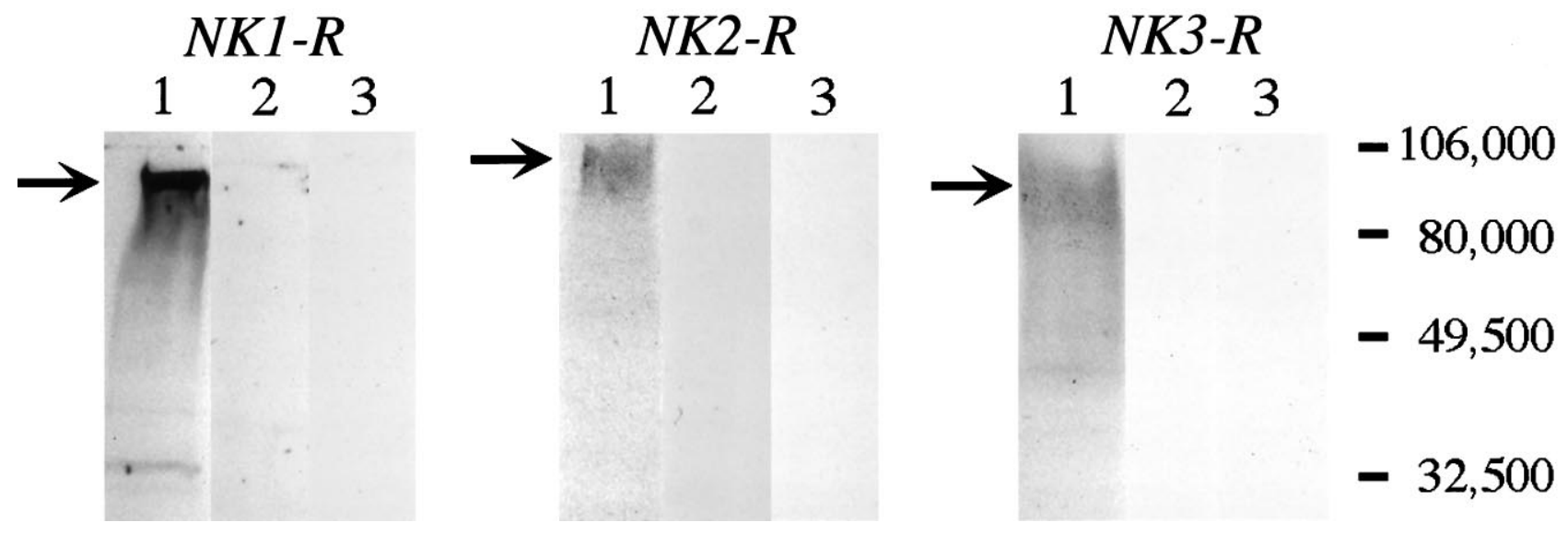

Figure 2. Western blot analysis using NK1-R antiserum (\#94168), NK2-R antiserum (\#94179), and NK3-R antiserum (\#94192). Each lane contains $10 \mu \mathrm{g}$ of protein. Lane 1, Transfected cells expressing NK1-R, NK2-R, or NK3-R. Lane 2, Transfected cells expressing NK1-R, NK2-R, or NK3-R, with antisera preabsorbed with receptor fragment. Lane 3, Nontransfected cells. The arrows indicate the major bands that were detected in transfected cells.

There was no detectable difference in the intensity of the staining within the circular muscle of the stomach or small intestine. The NK2-R was also detected in the muscularis mucosa of small intestine and colon (Fig. 4E). Appreciable levels of NK2-R immunoreactivity were not detected in the muscularis mucosa of the stomach. The NK2-R was localized to the plasma membrane of smooth muscle cells, where it was often of a beaded or granular appearance (Fig. $4 A, C-E, G$ ). In addition, the receptor was detected in a few endosomes in muscle cells, as seen in optical sections taken through the center of these cells (Fig. 4G). This was particularly evident when the cell outline was identified by a membrane marker (Fig. 4G,H). It was difficult to clearly visualize NK2-R in muscle cells in whole mounts of the ileum, probably because of its widespread distribution. The NK2-R was not detected in nerve cell bodies or processes of the myenteric or submucosal nerve plexuses. However, NK2-R was present on numerous nerve terminals in both the submucosal and the myenteric plexuses of the small intestine (Fig. $4 F$ ). There was no detectable staining when the antiserum was preabsorbed with the peptide that was used for immunization (Fig. 4B).

\section{NK3-R}

NK3-R was detected in neurons of the rat gastrointestinal tract using antisera \#94192 and \#AP951, which gave a similar pattern of staining in tissue sections and whole mounts (Fig. 5). Numerous stained neurons were detected in the myenteric and submucosal plexuses of the duodenum, jejunum, and ileum (Fig. 5A, $D, E, H)$. Immunoreactivity was particularly apparent in the soma of neurons, although it was also detected in fibers within the plexuses. In the gastric fundus and antrum, NK3-R was observed in neurons in the myenteric and submucosal plexuses, but there were fewer stained neurons than in the small intestine (Fig. $5 C$ ). In the proximal colon, NK3-R was detected in many myenteric and submucosal neurons (Fig. $5 F, G)$. Confocal microscopy showed that the plasma membrane of the neurons was clearly stained and that NK3-R was also detected in numerous endosomes, which were particularly apparent in the neuronal processes (Fig. $5 F-H$ ). More neurons were stained by NK3-R antiserum than by NK1-R antiserum. The NK3-R was not detected in the muscle layer. There was no detectable staining when the antiserum was preabsorbed with the peptide that was used for immunization (Fig. 5B).

\section{Simultaneous detection of tachykinins and neurokinin receptors}

To examine the relationship between nerve fibers containing tachykinins and cells expressing neurokinin receptors, we simultaneously incubated tissues with a monoclonal antiserum to tachykinins and the polyclonal antisera to the neurokinin receptors. The specificity of the monoclonal antiserum was established by preincubating the diluted antiserum with $1 \mu \mathrm{M} \mathrm{SP}$, NKA, or NKB overnight at $4^{\circ} \mathrm{C}$ before incubation with tissue sections. Preabsorption with SP, NKA, or NKB abolished staining. Thus, the antiserum recognizes sequences in the $\mathrm{C}$ terminus that are common to SP, NKA, and NKB.

Tachykinin immunoreactivity was detected in varicosities in nerve fibers in the myenteric and submucosal plexuses and in the circular and longitudinal muscle layers. Tachykinin-containing nerve fibers surrounded all NK1-R-expressing neurons in the myenteric and submucosal plexuses (Fig. 6A,B). In addition, they outlined the soma of neurons that did not stain with the NK1-R antiserum (Fig. $6 B$, asterisk). The interstitial cells of Cajal, which were stained with the NK1-R antiserum, were also closely associated with tachykinincontaining nerve fibers (Fig. $6 C$ ). Within the circular muscle layer, all of the myocytes expressed the NK2-R, but tachykinin-containing fibers were adjacent to only a small proportion of muscle cells (Fig. $6 D, E)$. Tachykinin-containing nerve fibers also surrounded NK3-R expressing neurons in the myenteric and submucosal plexuses (Fig. $6 F, G)$. However, they also outlined the soma of some neurons that were not stained with the NK3-R antiserum (Fig. $6 G$, asterisk). Thus, it is likely that receptor-bearing cells are innervated by tachykinincontaining nerve fibers.

In each case, there was no evidence that the neurokinin receptors were concentrated to a region of a neuron, interstitial cell of Cajal, or muscle cell that was in close apposition to tachykinincontaining varicosities. Thus, in the case of the NK1-R in nerve cells and interstitial cells of Cajal, tachykinin immunoreactivity was detected in varicosities adjacent to each cell, but there was no evidence for greater receptor immunoreactivity at these sites (Fig. $6 A-C)$. All of the muscle cells showed NK2-R immunoreactivity, but tachykinin-containing fibers were adjacent to only a small proportion of these cells that showed no greater NK2-R immunoreactivity than cells in the bulk of the muscle (Fig. 6D,E). NK3-R on nerve cells showed a similar dispersed localization as 

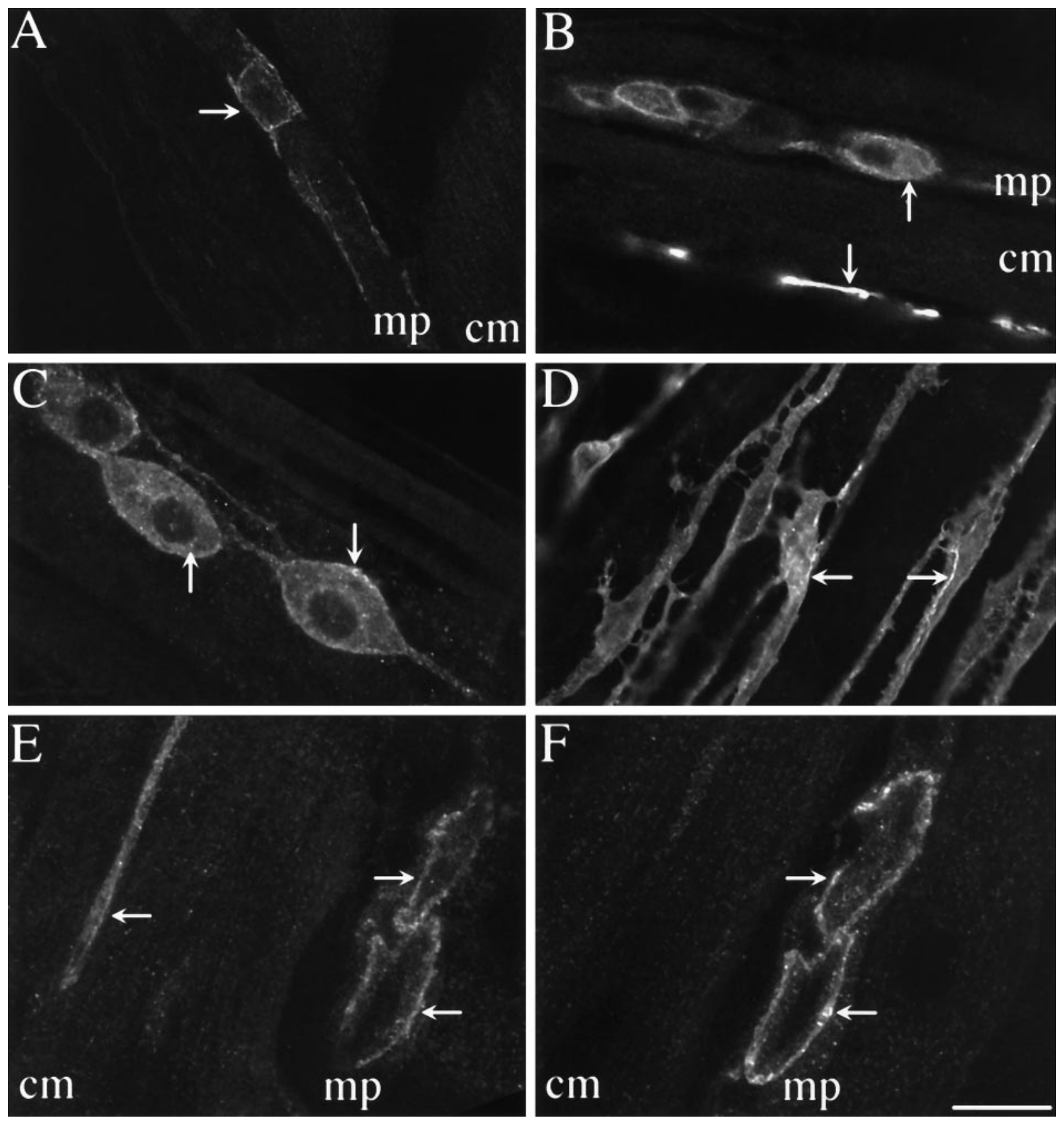

Figure 3. Confocal photomicrographs showing localization of NK1-R $(A-E)$ and NK3-R $(F)$ in tissue sections and whole mounts. Tissues were incubated with NK1-R antiserum \#94168 or NK3-R antiserum AP951. $A$, Section of antrum, showing localization of NK1-R in myenteric neurons. $B$, Section of jejunum, showing localization of NK1-R in myenteric neurons and interstitial cells of Cajal. $C$, Whole mount of the myenteric plexus of the ileum. $D$, Whole mount of interstitial cells of Cajal of the ileum. The arrows indicate prominent staining of the plasma membrane and endosomes. $E$, The sum of five optical sections of jejunum, collected at $0.36 \mu \mathrm{m}$ intervals, showing localization of NK1-R in myenteric neurons and in interstitial cells of Cajal. $F$, An adjacent section to $E$ ( $8 \mu \mathrm{m}$ apart), the sum of five optical sections showing localization of NK3-R. The same neurons expressing the NK1-R express the NK3-R, whereas the interstitial cells are unstained. $B-E$ show NK1-R-immunoreactive endosomes. $m p$, Myenteric plexus; $c m$, circular muscle. Scale bar (shown in $F$ ): $A-D, 20 \mu \mathrm{m} ; E, F, 13 \mu \mathrm{m}$.

the NK1-R, with no detectable concentration in relation to tachykinin-containing varicosities (Fig. $6 F, G$ ). Thus, the neurokinin receptors are quite uniformly distributed on a cell and not clustered close to tachykinin-containing nerve fibers.

\section{DISCUSSION}

This is the first detailed comparison of the distribution of all three tachykinin receptors in the gastrointestinal tract of the rat using specific antibodies. Our antibodies are specific, because they (1) stained transfected cells expressing the appropriate receptors, (2) did not stain cell lines and tissues if preabsorbed with the receptor fragments, and (3) identified appropriately sized proteins by Western blotting ( $80-100 \mathrm{kDa})$. Similar molecular weights have been reported for the NK1-R and NK3-R (Vigna et al., 1994; Kage et al., 1995; Ding et al., 1996). Although the neurokinin receptors have predicted molecular weights of 44-51 kDa, glycosylation would increase the molecular weights (Ohkubo and Nakanishi, 1991). 

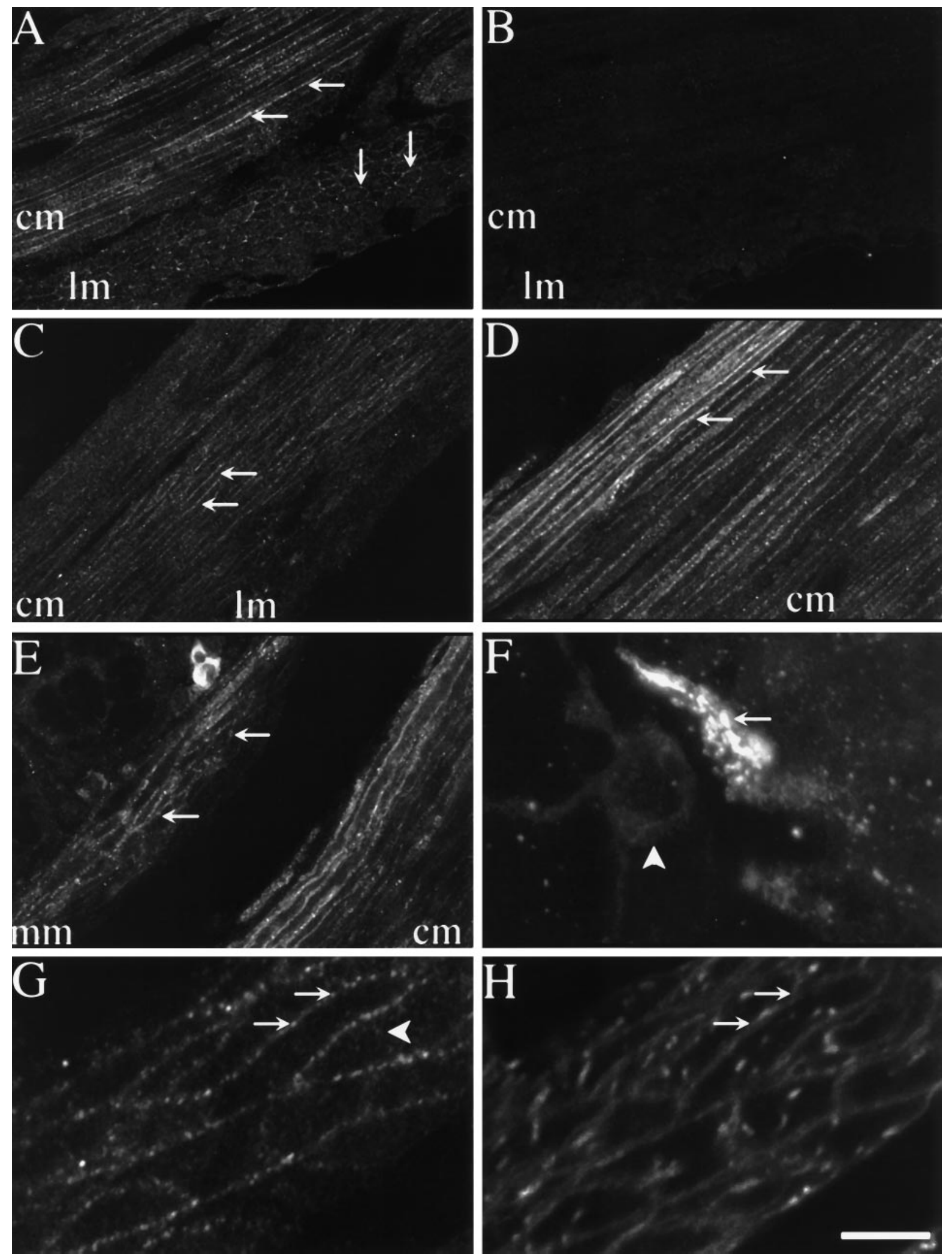

Figure 4. Confocal photomicrographs showing localization of NK2-R in tissue sections and whole mounts. Tissues were incubated with NK2-R antiserum \#94179. $A$, Section of circular and longitudinal muscle layers of the duodenum. $B$, Serial section from $A$ in which the antiserum is preabsorbed with 1 $\mu \mathrm{m}$ of the receptor fragment that was used for immunization. $C$, Section of circular and longitudinal muscle layers of the fundus. $D$, Section of circular muscle layer of the colon. $E$, Section of muscularis mucosa and circular muscle layer of the colon. The muscularis mucosa is identified by arrows. $F$, The sum of 10 optical sections, collected at $0.54 \mu \mathrm{m}$ intervals, of a whole mount of the submucosal plexus of the ileum showing a stained nerve ending. $G$, Section of circular muscle of the fundus. The arrows indicate prominent staining of the plasma membrane. The arrowhead indicates endosomes. $H$, Image of the same optical section shown in $G$, showing staining with Cell Tracker CM-DiI to outline the cell surface. $m p$, Myenteric plexus; $\mathrm{cm}$, circular muscle; $l m$, longitudinal muscle; $m m$, muscularis mucosa. Scale bar (shown in $H$ ): $A-E, 20 \mu \mathrm{m} ; F, 10 \mu \mathrm{m} ; G, H, 5 \mu \mathrm{m}$. 

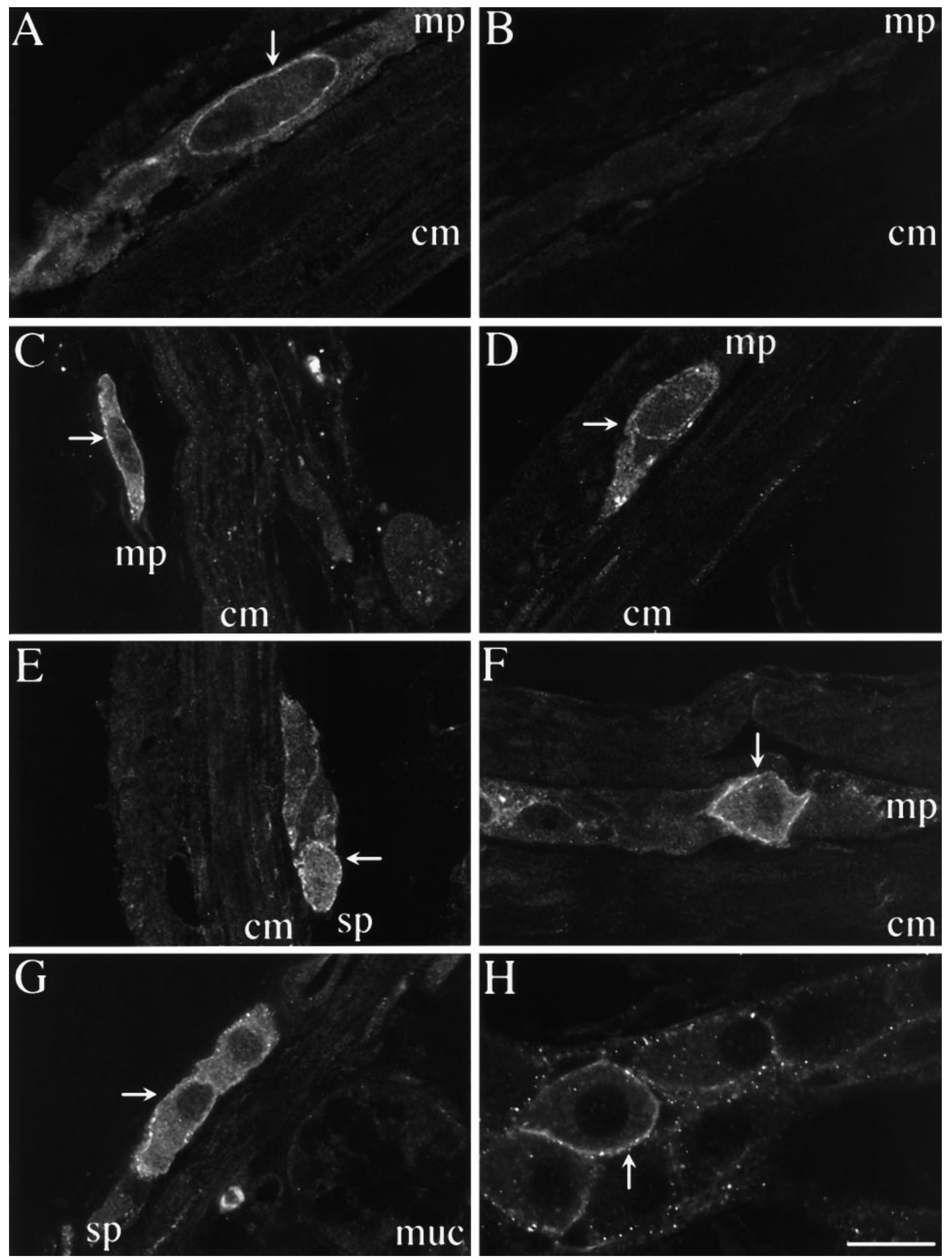

Figure 5. Confocal photomicrographs showing localization of NK3-R in tissue sections and whole mounts. Tissues were incubated with NK3-R antiserum \#94192 in $A, B, D$, and $E$, or AP951 in $C, F, G$, and $H . A$, Section of duodenum, showing localization of NK3-R in myenteric neurons. $B$, Serial section from $A$ in which the antiserum is preabsorbed with $1 \mu \mathrm{M}$ of the receptor fragment that was used for immunization. $C$, Section of fundus, showing localization of NK3-R in myenteric neurons. $D$, Section of jejunum, showing localization of NK3-R in myenteric neurons. $E$, Section of ileum, showing localization of NK3-R in submucosal neurons. $F$, Section of colon, showing localization of NK3-R in myenteric neurons. $G$, Section of colon, showing localization of NK3-R in submucosal neurons. $H$, Whole mount of the myenteric plexus of the ileum showing NK3-R at the plasma membrane and in endosomes. The arrows indicate prominent staining of the plasma membrane and endosomes. $m p$, Myenteric plexus; $s p$, submucosal plexus; $c m$, circular muscle; $l m$, longitudinal muscle; $m u c$, mucosa. Scale bar (shown in $H$ ), $20 \mu \mathrm{m}$. 

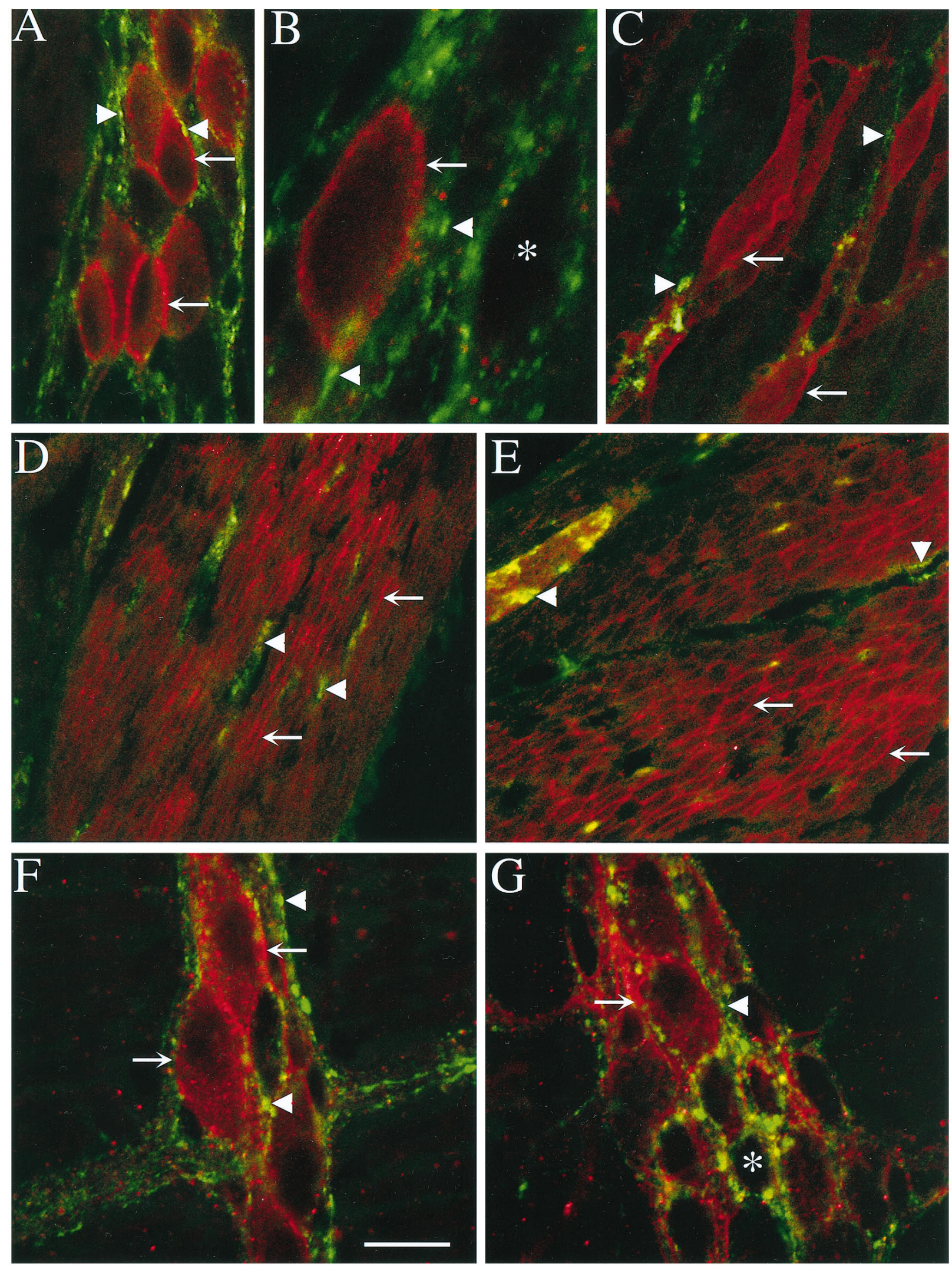

Figure 6. Confocal photomicrographs showing localization of neurokinin receptors (red, arrows) and tachykinins (green, arrowheads). A-C, NK1-R and tachykinins in whole mounts of the ileal myenteric plexus $(A, B)$ and interstitial cells of Cajal $(C) . D, E$, NK2-R and tachykinins in the gastric antrum. $F, G, \mathrm{NK} 3-\mathrm{R}$ and tachykinins in whole mounts of the ileal myenteric plexus. Cells expressing the neurokinin receptors (arrows) are closely associated with tachykinin containing nerve fibers (arrowheads). Not all neurons within a plexus express a given neurokinin receptor (asterisks), but all neurons are surrounded by tachykinin-containing fibers. Scale bar (shown in $F$ ): $A, C, E-G, 20 \mu \mathrm{m} ; B, 10 \mu \mathrm{m} ; D, 30 \mu \mathrm{m}$. 


\section{Localization of neurokinin receptors in the gastrointestinal tract}

NK1-R

Our detection of NK1-R immunoreactivity in enteric neurons and interstitial cells of Cajal is supported by previous studies using a different antiserum (Vigna et al., 1994; Sternini et al., 1995; Portbury et al., 1996) and with the localization of SP binding sites by autoradiography (Burcher et al., 1984, 1986; Mantyh et al., 1989). SP binds to myenteric and submucosal neurons, and stimulation of rat neurons containing SP results in slow EPSPs in follower cells, which are blocked by SP antiserum and that may be mediated by the NK1-R (Willard, 1990). SP binding sites are found in the innermost layers of the circular muscle in the rat intestine (Burcher et al., 1984, 1986; Mantyh et al., 1989), but this binding may be to interstitial cells of Cajal that were intensely stained by our antiserum and restricted to the small intestine, which may explain the higher expression of NK1-R mRNA in the intestine than the stomach (Tsuchida et al., 1990). The NK1-R has also been detected in the circular muscle of the guinea pig ileum by use of selective agonists and antagonists (Maggi et al., 1990), although contractile effects could have been attributable to activation of the receptor on interstitial cells of Cajal, which regulate contractile activity of the intestine (Ward and Sanders, 1990). We did not detect NK1-R in longitudinal muscle, although low levels of SP binding are found in the longitudinal muscle of the rat stomach and intestine (Burcher et al., 1984, 1986; Mantyh et al., 1989), and low numbers of NK1-Rs have been detected in longitudinal muscle of the rat duodenum by using selective agonists and antagonists (Rahman et al., 1994). It is possible that the NK1-R is expressed at very low levels by muscle tissue and, therefore, is beyond the sensitivity of detection by immunofluorescence. Alternatively, muscle cells may express a subtype, perhaps one that is truncated at the C terminus (Fong et al., 1992; Kage et al., 1993), which would not be detected by our antiserum.

\section{$N K 2-R$}

Our detection of the NK2-R immunoreactivity in muscle is also supported by localization of NKA-binding sites on muscle cells by autoradiography (Burcher et al., 1984, 1986; Mantyh et al., 1989; Mussap and Burcher, 1993). Both methods show localization to muscle cells rather than nerves and marked regional differences in expression throughout the gastrointestinal tract. We detected high levels of NK2-R immunoreactivity in circular muscle, and NKA binds to circular muscle of the rat pylorus, fundus, colon, and proximal duodenum with decreasing intensity (Burcher et al., 1984, 1986; Mantyh et al., 1989; Mussap and Burcher, 1993). We found lower NK2-R immunoreactivity in the longitudinal muscle, and there are fewer NKA-binding sites in this tissue. We detected NK2-R in the muscularis mucosa of the small intestine and colon, and NKA also binds to the muscularis mucosa of the stomach and colon (Burcher et al., 1986; Mantyh et al., 1989; Mussap et al., 1993). The intense staining for NK2-R in the gastric antrum may explain its high expression of NK2-R mRNA (Tsuchida et al., 1990). Functional experiments support the localization of the NK2-R to muscle cells. For example, contractile responses of longitudinal muscle of the rat duodenum and circular muscle of the guinea pig ileum to NK2-R-selective agonists are unaffected by tetrodotoxin, confirming the presence of NK2-R in muscle (Bergström et al., 1987; Maggi et al., 1990, 1994; Bartho et al., 1992; Rahman et al., 1994). However, we also detected NK2-R in nerve endings but not cell bodies in the submucosal and myenteric plexuses. In dogs, NKA binds to the myenteric plexus, where it may identify nerve endings (Mantyh et al., 1988).

\section{NK3-R}

Our detection of a large population of enteric neurons with NK3-R immunoreactivity contradicts the results of binding studies, which failed to detect NK3-R in the gastrointestinal tract (Mantyh et al., 1988, 1989; Gates et al., 1989). However, low levels of NK3-R mRNA are found in the rat stomach and intestine (Tsuchida et al., 1990). In the rat brain, in situ hybridization for NK3-R mRNA agrees well with immunohistochemical results, and although it generally agrees with previous binding data there are some discrepancies (Ding et al., 1996). Functional experiments support the neuronal localization of the NK3-R. The NK3-R agonists NKB, eledoisin, senktide, and $\left[\mathrm{MePhe}^{7}\right]-\mathrm{NKB}$ stimulate contraction of rat duodenum and guinea pig ileum (Laufer et al., 1985, 1988; Kilbinger et al., 1986; Guard and Watson, 1987; Maggi et al., 1990). The responses of the guinea pig ileum are abolished by tetrodotoxin and reduced by atropine, which indicates the presence of NK3-R on cholinergic neurons of the myenteric plexus (Guard and Watson, 1987). Indeed, senktide stimulates acetylcholine release from myenteric neurons (Guard et al., 1991; Yau et al., 1992). Desensitization or antagonism of the NK1-R markedly reduces the atropine-resistant contractile response, suggesting that release of tachykinins and activation of the NK1-R contributes to senktide-stimulated contraction (Guard and Watson, 1987). Thus, our finding that neurons in the myenteric plexus can express both NK1-R and NK3-R is of particular interest.

\section{Simultaneous localization of tachykinins and neurokinin receptors}

Our tachykinin antibody probably reacted primarily with SP, NKA, neuropeptide K, and neuropeptide $\gamma$ because these peptides and their precursor mRNAs are readily detected in the rat intestine (Sternini et al., 1989; Carter and Krause, 1990; Takeda et al., 1990; Krause et al., 1992), whereas NKB and its precursor mRNA are expressed in low levels in the gut (Tateishi et al., 1990). Thus, nerve fibers containing SP and NKA are well situated to stimulate NK1-R and NK2-R, their preferred receptors. Although sufficient NKB may be available to activate the NK3-R, the other tachykinins may be the natural agonists of the NK3-R in the gut. The affinity of the NK3-R for NKB is $\sim 100$-fold higher than for NKA (Ohkubo and Nakanishi, 1991), but the concentration of NKA in small intestine is $>40$-fold higher than NKB (Tateishi et al., 1990). Thus, if high local concentrations are achieved, NKA could stimulate the NK3-R. Indeed, the ability of SP and NKA to stimulate the NK3-R has been a strong argument for use of more specific agonists for receptor characterization (Maggi et al., 1994). It is also possible that our NK3-R antiserum detected a variant of the NK3-R with altered selectivity for the tachykinins, and receptor subtypes have been suggested by pharmacological approaches (Maggi et al., 1994; Rahman et al., 1994; Regoli et al., 1994). Supporting altered NK3-R affinity in the gut is the inability to detect binding sites for the NKB analog eledoisin in the gut but not the CNS (Mantyh at al., 1988, 1989).

We did not detect concentrations of neurokinin receptor immunoreactivity adjacent to tachykinin-containing varicosities. Tachykinin-containing varicosities were apposed to neurons and interstitial cells of Cajal expressing NK1-R or NK3-R, but there was no greater receptor immunoreactivity at these sites. Tachykinin-containing fibers were adjacent to only a small pro- 
portion of myocytes that showed no greater NK2-R immunoreactivity than other muscle cells. Possibly not all muscle cells are innervated or tachykinins diffuse considerable distances in muscle tissue. Indeed, NKA can diffuse throughout the dorsal horn of the spinal cord, where it may be more resistant to proteolytic degradation than SP (Duggan et al., 1990). Less dense innervation of muscle may be appropriate because the cells are electrically coupled (Furness and Costa, 1987). Together, our findings agree with results obtained in the CNS, where NK1-R is distributed over $\sim 70 \%$ of the surface of neurons in a noncontinuous manner (Liu et al., 1994), in marked contrast to acetylcholine receptors, which are clustered at synapses. However, our finding of NK2-R at nerve terminals suggests that uniform distribution is not a universal phenomenon for neuropeptide receptors.

\section{Subcellular localization of neurokinin receptors}

Neurokinin receptors were present at the cell surface and in endosomes of neurons, interstitial cells, and myocytes. SP and NKA stimulate endocytosis and recycling of NK1-R and NK2-R (Bowden et al., 1994; Garland et al., 1994, 1996; Grady et al., 1995, 1996; Mantyh et al., 1995). Therefore, the presence of receptors in endosomes may be attributable to the baseline release of endogenous tachykinins. Some surface NK1-R may exist in a low-affinity state and be unable to bind SP (Grady et al., 1995). Thus, receptors that were detected at the plasma membrane may have not been exposed to agonists or be in a very low-affinity state and unable to interact with tachykinins. Alterations in the subcellular distribution of NK1-Rs have important functional consequences. Depletion of NK1-Rs from the plasma membrane contributes to desensitization, which is also mediated by receptor phosphorylation and interaction with arrestins (Kwatra et al., 1993; Sasakawa et al., 1994). Resensitization requires phosphatase activity and NK1-R recycling (Garland et al., 1996). The mechanisms of desensitization and resensitization of the NK2-R and NK3-R have not been examined in detail, but the availability of these antisera will facilitate these studies.

\section{REFERENCES}

Bartho L, Santicioli P, Patacchini R, Maggi CA (1992) Tachykininergic transmission to the circular muscle of the guinea-pig ileum: evidence for the involvement of NK2 receptors. Br J Pharmacol 105:805-810.

Bergström L, Beaujouan JC, Torrens Y, Saffroy M, Glowinski J, Lavielle S, Chassaing G, Marquet A, D'Orleans-Juste P, Dion S, Regoli D (1987) ${ }^{3}$ H-neurokinin A labels a specific tachykinin-binding site in the rat duodenal smooth muscle. Mol Pharmacol 32:764-771.

Bowden JJ, Garland AM, Baluk P, Lefevre P, Grady EF, Vigna SR, Bunnett NW, McDonald DM (1994) Direct observation of substance P-induced internalization of neurokinin 1 (NK1) receptors at sites of inflammation. Proc Natl Acad Sci USA 91:8964-8968.

Bunnett NW, Dazin PF, Payan DG, Grady EF (1995) Characterization of receptors using cyanine 3-labeled neuropeptides. Peptides 16:733-740.

Burcher E, Shults CW, Buck SH, Chase TN, O'Donohue TL (1984) Autoradiographic distribution of substance $\mathrm{K}$ binding sites in rat gastrointestinal tract: a comparison with substance P. Eur J Pharmacol 102:561-562.

Burcher E, Buck SH, Lovenberg W, O’Donohue TL (1986) Characterization and autoradiographic localization of multiple tachykinin binding sites in gastrointestinal tract and bladder. J Pharmacol Exp Ther 236:819-831.

Burcher E, Badgery-Parker T, Zheng X-P, Lavielle S (1993) Characterization of a novel, selective radioligand, $\left[{ }^{125} \mathrm{I}\right]\left[\mathrm{Lys}{ }^{5}, \operatorname{Tyr}\left(\mathrm{I}_{2}\right)^{7}\right.$, MeLeu $\left.{ }^{9}, \mathrm{Nle}^{10}\right]$ neurokinin A-(4-10), for the tachykinin $\mathrm{NK}_{2}$ receptor in rat fundus. Eur J Pharmacol 233:201-207.

Carter MS, Krause JE (1990) Structure, expression, and some regulatory mechanisms of the rat preprotachykinin gene encoding substance $\mathrm{P}$, neurokinin A, neuropeptide $\mathrm{K}$, and neuropeptide $\gamma$. J Neurosci 10:2203-2214.
Ding Y-Q, Shigemoto R, Takada M, Ohishi H, Nakanishi S, Mizuno N (1996) Localization of the neuromedin $\mathrm{K}$ receptor $\left(\mathrm{NK}_{3}\right)$ in the central nervous system of the rat. J Comp Neurol 364:290-310.

Duggan AW, Hope PJ, Jarrott B, Schaible H-G, Fleetwood-Walker SM (1990) Release, spread and persistence of immunoreactive neurokinin A in the dorsal horn of the cat following noxious cutaneous stimulation: studies with antibody microprobes. Neuroscience 35:195-202.

Fong TM, Anderson S, Yu H, Huang R-RC, Strader CD (1992) Differential activation of intracellular effector by two isoforms of human neurokinin-1 receptor. Mol Pharmacol 41:24-30.

Furness JB, Costa M (1987) The enteric nervous system. Edinburgh, Scotland: Churchill Livingstone.

Garland AM, Grady EF, Payan DG, Vigna SR, Bunnett NW (1994) Agonist-induced internalization of the substance $\mathrm{P}$ (NK1) receptor expressed in epithelial cells. Biochem J 303:177-186.

Garland AM, Grady EF, Lovett M, Vigna SR, Frucht MM, Krause JE, Bunnett NW (1996) Mechanisms of desensitization and resensitization

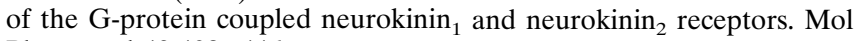
Pharmacol 49:438-446.

Gates TS, Zimmerman RP, Mantyh CR, Vigna SR, Maggio JE, Welton ML, Passaro EP, Mantyh PW (1989) Substance P and substance K receptor binding sites in the human gastrointestinal tract: localization by autoradiography. Peptides 9:1207-1219.

Grady EF, Garland AG, Gamp PD, Lovett M, Payan DG, Bunnett NW (1995) Delineation of the endocytic pathway of substance P and the seven transmembrane domain NK1 receptor. Mol Biol Cell 6:509-524.

Grady EF, Gamp PD, Baluk P, McDonald DM, Payan DG, Bunnett NW (1996) Endocytosis and recycling of NK1 tachykinin receptors in enteric neurons. Neuroscience, in press.

Guard S, Watson SP (1987) Evidence for neurokinin-3 receptormediated tachykinin release in the guinea-pig ileum. Eur J Pharmacol 144:409-412.

Guard S, McKnight AT, Watling KJ, Watson SP (1991) Evidence for two types of tachykinin receptors on cholinergic neurons of the guinea pig ileum myenteric plexus. In: Substance $P$ and related peptides: cellular and molecular physiology (Leeman SE, Krause JE, Lembeck F, eds), pp 400-403. New York: New York Academy of Sciences.

Helke CJ, Krause JE, Mantyh PW, Couture R, Bannon MJ (1990) Diversity in mammalian tachykinin peptidergic neurons: multiple peptides, receptors, and regulatory mechanisms. FASEB J 4:1606-1615.

Hershey AD, Krause JE (1990) Molecular characterization of a functional cDNA encoding the rat substance $\mathrm{P}$ receptor. Science 247:958-962.

Ingi T, Kitajima Y, Minamitake Y, Nakanishi S (1991) Characterization of ligand-binding properties and selectivities of three rat tachykinin receptors by transfection and functional expression of their cloned cDNAs in mammalian cells. J Pharmacol Exp Ther 259:968-975.

Kage R, Leeman SE, Boyd ND (1993) Biochemical characterization of two different forms of the substance $\mathrm{P}$ receptor in rat submaxillary gland. J Neurochem 60:347-351.

Kage R, Hershey AD, Krause JE, Boyd ND, Leeman SE (1995) Characterization of the substance $\mathrm{P}$ (NK1-R) receptor in tunicamycintreated transfected cells using a photoaffinity analogue of substance P. J Neurochem 64:316-321.

Kilbinger H, Staub P, Erlhof I, Holzer P (1986) Antagonist discrimination between subtypes of tachykinin receptors in the guinea-pig ileum. Naunyn Schmiedebergs Arch Pharmacol 334:181-187.

Krause JE, Takeda Y, Hershey AD (1992) Structure, functions, and mechanisms of substance $\mathrm{P}$ receptor action. J Invest Dermatol 98:2S-7S.

Kwatra MM, Schwinn DA, Schreurs J, Blank JL, Kim CM, Benovic JL, Krause JE, Caron MG, Lefkowitz RJ (1993) The substance P receptor, which couples to $\mathrm{Gq} / 11$, is a substrate of $\beta$-adrenergic receptor kinase 1 and 2. J Biol Chem 268:9161-9164.

Laemmli UK (1970) Cleavage of structural proteins during the assembly of the head of bacteriophage T4. Nature 227:680-685.

Laufer R, Wormser U, Friedman ZY, Gilon C, Chorev M, Selinger Z (1985) Neurokinin B is a preferred agonist for a neuronal substance $P$ receptor and its action is antagonized by enkephalin. Proc Natl Acad Sci USA 82:7444-7448.

Laufer R, Gilon C, Chorev M, Selinger Z (1988) Desensitization with a selective agonist discriminates between multiple tachykinin receptors. J Pharmacol Exp Ther 245:639-643.

Liu H, Brown JL, Jasmin L, Maggio JE, Vigna SR, Mantyh PW, Basbaum AI (1994) Synaptic relationship between substance $P$ and the sub- 
stance $\mathrm{P}$ receptor: light and electron microscopic characterization of the mismatch between neuropeptides and their receptors. Proc Natl Acad Sci USA 91:1009-1013.

Maggi CA, Patacchini R, Giachetti A, Meli A (1990) Tachykinin receptors in the circular muscle of the guinea-pig ileum. Br $\mathrm{J}$ Pharmacol 101:996-1000.

Maggi CA, Patacchini R, Meini S, Quartara L, Sisto A, Potier E, Giuliani S, Giachetti A (1994) Comparison of tachykinin NK1 and NK2 receptors in the circular muscle of the guinea-pig ileum and proximal colon. Br J Pharmacol 112:150-160.

Mantyh PW, Mantyh CR, Gates TS, Vigna SR, Maggio JE (1988) Receptor binding sites for substance $\mathrm{P}$ and substance $\mathrm{K}$ in the canine gastrointestinal tract and their possible role in inflammatory bowel disease. Neuroscience 25:817-837.

Mantyh PW, Gates T, Mantyh CR, Maggio JE (1989) Autoradiographic localization and characterization of tachykinin receptor binding sites in the rat brain and peripheral tissues. J Neurosci 9:258-279.

Mantyh PW, Allen CJ, Ghilardi JR, Rogers SD, Mantyh CR, Liu H, Basbaum AI, Vigna SR, Maggio JE (1995) Rapid endocytosis of a G protein-coupled receptor: substance $\mathrm{P}$ evoked internalization of its receptor in the rat striatum in vivo. Proc Natl Acad Sci USA 92:2622-2626.

Mussap CJ, Burcher E (1993) Characterization and autoradiographic localization of tachykinin receptors in rat gastric fundus. J Pharmacol Exp Ther 266:1043-1053.

Okamoto A, Lovett M, Payan DG, Bunnett NW (1994) Interactions between neutral endopeptidase (EC 3.4.24.11) and the substance $P$ (NK1) receptor expressed in mammalian cells. Biochem J 299:683-693.

Ohkubo H, Nakanishi S (1991) Molecular characterization of the three tachykinin receptors. In: Substance $P$ and related peptides: cellular and molecular physiology (Leeman SE, Krause JE, Lembeck F, eds), pp 53-62. New York: New York Academy of Sciences.

Otsuka M, Yoshioka K (1993) Neurotransmitter functions of mammalian tachykinins. Physiol Rev 73:229-308.

Portbury AL, Furness JB, Young HM, Southwell BR, Vigna SR (1996) Localisation of NK1 receptor immunoreactivity to neurons and interstitial cells of the guinea-pig gastrointestinal tract. J Comp Neurol 367:342-351.

Rahman M, Lördal M, Al-Saffar A, Hellström PM (1994) Intestinal motility responses to neuropeptide $\gamma$ in vitro and in vivo in the rat: comparison with neurokinin 1 and neurokinin 2 receptor agonists. Acta Physiol Scand 151:497-505.

Regoli D, Boudin A, Fauchere J-L (1994) Receptors and antagonists for substance $\mathrm{P}$ and related peptides. Pharmacol Rev 46:551-599.
Sasai Y, Nakanishi S (1989) Molecular characterization of rat substance $\mathrm{K}$ receptor and its mRNAs. Biochem Biophys Res Commun 165:695-702.

Sasakawa N, Ferguson JE, Sharif M, Hanley MR (1994) Attenuation of agonist-induced desensitization of the rat substance $\mathrm{P}$ receptor by microinjection of inositol pentakis- and hexakisphosphates in Xenopus laevis oocytes. Mol Pharmacol 46:380-385.

Shigemoto R, Yokota Y, Tsuchida K, Nakanishi S (1990) Cloning and expression of a rat neuromedin $\mathrm{K}$ receptor cDNA. J Biol Chem 265:623-628.

Sternini C, Anderson K, Frantz G, Krause JE, Brecha N (1989) Expression of substance $\mathrm{P} /$ neurokinin A-encoding preprotachykinin messenger ribonucleic acids in the rat enteric nervous system. Gastroenterology 97:348-356.

Sternini C, Su D, Gamp PD, Bunnett NW (1995) Cellular sites of expression of the neurokinin-1 receptor in the rat gastrointestinal tract. J Comp Neurol 358:531-530.

Takeda Y, Takeda J, Smart BM, Krause JE (1990) Regional distribution of neuropeptide $\gamma$ and other tachykinin peptides derived from the substance $\mathrm{P}$ gene in the rat. Regul Pept 28:323-333.

Tateishi K, Kishimoto S, Kobayashi H, Kobuke K, Matsuoka Y (1990) Distribution and localization of neurokinin A-like immunoreactivity and neurokinin B-like immunoreactivity in rat peripheral tissue. Regul Pept 30:193-200.

Tsuchida K, Shigemoto R, Yokota Y, Nakanishi S (1990) Tissue distribution and quantitation of the mRNAs for three rat tachykinin receptors. Eur J Biochem 193:751-757.

Vigna SR, Bowden JJ, McDonald DM, Fisher J, Okamoto A, McVey DC, Payan DG, Bunnett NW (1994) Characterization of antibodies to the rat substance $\mathrm{P}\left(\mathrm{NK}_{1}\right)$ receptor and to a chimeric substance $\mathrm{P}$ receptor expressed in mammalian cells. J Neurosci 14:834-845.

Ward SM, Sanders KM (1990) Pacemaker activity in septal structures of canine colonic circular muscle. Am J Physiol 259:G264-G273.

Willard AL (1990) Substance P mediates synaptic transmission between rat myenteric neurones in cell culture. J Physiol (Lond) 426:453-471.

Yau WM, Mandel KG, Dorsett JA, Youther ML (1992) Neurokinin 3 receptor regulation of acetylcholine release from myenteric plexus. Am J Physiol 263:G659-G664.

Yokota Y, Sasai Y, Tanaka K, Fujiwara T, Tsuchida K, Shigemoto R, Kakizuka A, Ohkubo H, Nakanishi S (1989) Molecular characterization of a functional cDNA for rat substance $\mathrm{P}$ receptor. J Biol Chem 264:17649-17652. 